$\xi=-1$

\title{
The inter-organizational linkages in the implementation of self-helping housing stimulant program
}

\author{
Candradewini Candradewini ${ }^{1 *}$, Budiman Rusli ${ }^{1}$, Entang Adhy Muhtar ${ }^{1}$ \\ ${ }^{1}$ Public Administration Department, Social and Political Sciences Faculty Universitas Padjadjaran \\ *Corresponding author E-mail: candradewini@gmail.com
}

\begin{abstract}
Cirebon Regency is the regency that has the fastest implementation progress among the regencies/cities receiving the Self-Helping Housing Stimulant in West Java Province. The initial observations and interviews from this research indicate that one of the supporters of the development of this program is the good relationship between the parties involved in the implementation of this program. This study aims to explain inter-organizational linkages between the parties associated with this program. The research method used qualitative approach. Data and information is obtained through in-depth interview, observation and documentation study. The informants in this research are institutions related to the poor community housing improvement program consisting of local government, district government, village government and community in Klangenan District, Cirebon Regency. The result of the research explains that interorganizational linkages among the parties that run the program of house improvement in Cirebon Regency is going well. The facilitators of this program are proactive in communicating and establishing working relationships with beneficiary communities. This condition is reinforced by the cultural value of "ngersaya," which is a value of life of the local population in the form of repayment and nurturing kinship with those who have helped. Nevertheless, there are still some problems and obstacles faced such as the intensity of face-to-face is still rare and coordination meetings that have not scheduled regularly, especially with the technical team of the Government of Cirebon Regency. This research found that cultural value has a significant role in inter-organizational linkages between parties.
\end{abstract}

Keywords: Inter-Organizational Linkages, Self-Helping Housing Stimulant Program

\section{Introduction}

The rapid rate of population growth in Indonesia has caused the need for homes each year to increase. Meanwhile, the condition of housing availability has not been able to meet the increase.

The imbalance between the demand and supply of the home has become a major problem in providing basic needs in the form of houses, especially for Low Income Communities. Low-Income Communities are people who have limited purchasing power so they need government support to get a decent home.

The low affordability in meeting the needs of the home is one of the reasons why many low-income communities have not lived or have a decent house to live in. This has the potential to lead to the emergence of slums and the decline in the quality of healthy and decent housing. Based on data from the Central Bureau of Statistics 2015 there are 2.51 million Unfit Homes that need to be improved the quality of his house along with facilities and infrastructure and housing utilities.

In order to support the development process of self-supporting houses that are habitable especially for Low-Income Communities, since 2006 the Ministry of Public Works and People's Housing has issued various policies in the form of Self-Helping Housing Stimulant Charity. As for the year 2016 has been stipulated Regulation of Minister of Public Works and People's Housing Number. 13 of 2016 on the Help of Self-Housing Stimulant. This policy is expected to encourage Low-Income Communities to have a habitable home as well as a comfortable environment. In this case, the construction of a habitable home may take the form of new housing construction, quality improvement, or the construction of public infrastructure and facilities.

Cirebon Regency is part of West Java Province and is located in the eastern part as well as the border and entrance gate of Central Java Province. Cirebon Regency has obtained Self-Help Housing Stimulant Charity almost every year. The type of assistance provided in Cirebon Regency is the improvement of quality with the amount of light quality improvement value IDR 7.500.000 and the medium quality improvement IDR 10.000 .000 and the weight quality improvement IDR 15.000 .000 .

In 2017 the beneficiaries of the Self-Helping Housing Stimulant in Cirebon Regency are located in Klangenan Sub-district, Jemaras Lor Village and Jemaras Kidul Village. In the implementation of the provision of assistance, of course, involves various parties including the managers at the level of the Ministry of Public Works and Public Housing, Regional Device Work Unit at the provincial and regency levels, Field Facilitators, Distributors Banks, Beneficiaries of Unsuitable Housing and parties others involved.

Cirebon Regency is the regency with the fastest success rate among beneficiary regencies/cities in West Java Province. Based on preliminary observations and interviews it is known that one that supports the success of this program is the existence of good cooperation and relationships between the parties as the program implementer. Based on this background, then this study aims to 
explain the inter-organizational linkages between the parties associated with this program.

\section{Theoretical review}

The rapid development of the environment has affected the lives of individuals, communities and organizations. The era of globalization that spread to all aspects of life has encouraged each party to be able to improve its ability. As Candradewini [1] writes, "Such conditions require the ability of each side to optimize all available resources while responding and adapting to environmental changes".

Environmental changes in public management processes require good capability or capacity from human resources dimensions and other dimensions as organizational resources as Starling [2] also describes the dimensions of the public management process, consisting of two main dimensions, "resource management" consisting of human components, finance and information and "program management" which consists of components planning, decisionmaking, organizing, leadership and implementation of the program. These two dimensions are at the heart of the administrative process that describes the conditions of administrative capacity or organizational capacity to transform policies, programs and activities within the public administration system.

Inter-organizational linkages have helped organizations to keep up with the progress or progress of other areas related to organizational goals. In addition, through this network, able to provide access to a very wide and up to date information. This is in line with the opinion of Coyne and Dye, that "Linkages helps the organization keep up with advances in pertinent fields, and provide access to the wide-ranging source of up-to-date information within each area of the organization's work" [3].

If the organization does not apply the networking aspects of its work, it will encounter obstacles caused by the lack of support from other organizations within the scope of its work. This condition is in line with the opinion of Lusthaus [3] that "Many organizations find that they are unable to move towards their mission without the help and support of like-minded organizations".

In this regard, networking in the delivery of public services is important and crucial considering the limitations of the public organization itself. Through networking and cooperation, organizations will be able to improve their capabilities and develop mechanisms to work together.

Similarly, in the implementation of a policy or program that is an important aspect of the overall policy process. It is explained by Udoji that "The execution of policies is as important as the policy making. Policies will remain dreams or blue print file jackets unless they are implemented" [4].

Meanwhile, Grindle argues that the success of a public policy implementation is largely determined by both content and policy context. One aspect of the content of policy is the resources commited, that is, the implementation of a policy must also be supported by the supporting resources in order to make the implementation work well [5]. Thus, the implementation of a policy or program requires cooperation between parties, whose scope is not only in the field of information but other areas that are related.

\section{Research method}

The research method used is a qualitative research method that will reveal in depth about the reality in the field. Data and information are collected through observation, interview, literature study and triangulation techniques to ensure data validity. The informants in this study are the managers of the Self-Helping Housing Stimulant Program in Cirebon Regency, including the Office of Housing and Settlement of West Java Province, the Office of Housing and Settlement of Cirebon Regency, field facilitators and beneficiaries in Jemaras Kidul Village and Jemaras Lor Village, Klangenan District, Cirebon Regency.

\section{Results and discussion}

The Self-Helping Housing Stimulant Charity is intended to improve the Low-Income Community initiatives in the construction or improvement of the quality of houses along with infrastructure, facilities and utilities. Thus, the establishment of a habitable home and supported by infrastructure, facilities and utilities became the objective of holding this Self-Helping Housing Stimulant Charity. In addition, another goal is to create healthy, safe, harmonious, organized and sustainable housing.

Ministry of Public Works and Public Housing through the Directorate General of Housing Provision is the provider of this assistance program. The aid program in the form of money is given to individual beneficiaries to be used to purchase building materials. In the event that the beneficiary does not have the capacity to implement New Development or Quality Improvement, assistance can be used for wages.

The implementation of this program involves various parties, namely the central government through the Ministry of Public Works and People's Housing, Local Government of West Java Province, Local Government of Cirebon Regency, Klangenan District Government and Village Government Jemaras Kidul and Jemaras Lor Village. While the community is the recipient of assistance and other residents who helped the recipients in improving the house.

The large number of parties involved in organizing the SelfHelping Housing Stimulant Charity requires effective interorganizational linkages. One form is the preparation of program implementation steps and communicated by the ministry. Steps for the provision of the Self-Helping Housing Stimulant Program represent a real inter-organizational linkages in the implementation of the Self-Helping Housing Stimulant Program. These steps are 1) Coordination with stakeholders, 2) Socialization of Prospective Beneficiaries of identification results, 3) Verification and Identification of Unsuitable Housing Handling Plans/Host Deficiencies, 4) Organizing Prospective Beneficiaries, 5) Formulating a form assistance proposal money, 6) Approval of proposal by technical team, 7) Propose proposal to Committing Officer, 8) Assignment of beneficiary, 9) Distribution of aid, 10) Selection of shop or provider of building materials and preparation of lists, 11) 12) Examination and acceptance of building materials phase I, 13) Construction phase I, 14) Physical reporting 30\%, 15) Evaluation and booking list phase II, 16) Booking materials phase II, 17) Inspection and acceptance of building materials phase II, 18 ) Phase II development, 19) $100 \%$ physical reporting.

\subsection{Inter-organizational linkages in implementation of self-helping housing stimulant program in Klangenan District, Cirebon Regency}

The steps to implement the Self-Helping Housing Stimulant Charity Program have been conducted by all parties related to the program. Some of the things that tend to require a harmonious and effective relationship between organizations will be discussed in the descriptions below.

\subsubsection{Coordination with stakeholders}

One of the important keys in inter-organizational linkages is the coordination between all stakholders. In this case involved are Ministry of Public Works and Housing, Office of Housing and Settlement of West Java Province, Office of Housing and Settlement of Cirebon District, field facilitators, and beneficiary communities in Klangenan Sub-district of Cirebon Regency. These parties have done a good job of coordinating effectively in the success of the Self-Helping Housing Stimulant Program. 
Facilitator and facilitator coordinators receive training on selfhelping housing stimulation activities and receive copies of the Minister of Public Works and People's Housing decree on location, the facilitator coordinator coordinates with stakeholders consisting of district government technical teams, channeling banks, commitment officials and others, to discuss the difficulties encountered in the distribution of building materials.

Village mobilization facilitator is the task to coordinate with the Village Head as a stakeholder, among others, prepare activities to conduct socialization to the Beneficiary.

\subsubsection{Socialization of prospective beneficiaries of identifica- tion results}

The socialization was conducted by the Field Facilitator Team accompanied by the Village Head as a member of the District/Municipal Technical Team attended by the Beneficiary with the socialization materials on. Activity Policy of the Self-Helping Housing Stimulant Charity granted by the government to lowincome communities that meet the criteria of the beneficiaries. In order for the application to be accepted then the Prospective Beneficiary must submit a proposal prepared together with the Beneficiary Group.

This socialization process shows that the relationship between the parties implemented in the implementation of this program. The socialization implemented in the Self-Helping Housing Stimulant Program in Klangenan Sub-district of Cirebon Regency is effective. This indicates that inter-organizational linkages work well. A good understanding of potential beneficiaries demonstrates the effectiveness of inter-related organizations in the program socialization.

\subsubsection{Inter-organizational linkages in the verification and identification activity}

The identification and verification is done by the Field Facilitator Team accompanied by the Village Head or representative of the Low-Income Community of potential beneficiaries already present in the Identification Data and the completeness of the documents. This verification activity involves various parties namely Field Facilitator Team, Village Head and Prospective Beneficiary. Relationship and mutual understanding in implementing verification steps in Klangenan District, Cirebon Regency has supported the implementation of the program to be more effective.

\subsubsection{The activities of the field facilitator team in organizing the prospective beneficiaries}

The field facilitator team performs the task of organizing the Beneficiary Candidates. The team facilitated the establishment of the Beneficiary Group.

a) Submitting verification results of the Beneficiary Candidates shall be stipulated in the Rembug Forum attended by the Beneficiary Candidate. The results of the Rembug are contained in the Minutes of Rembug Setting of Beneficiaries.

b) Accompany the participants of the Rembug Forum to form the Beneficiary Group, elect the chairman, secretary and treasurer of the Beneficiary Group, to sign a social agreement, in accordance with the Minutes of Group Formation and the Social Agreement.

\subsection{Culture "Ngersaya" as local value and its relation with inter-organizational linkages}

Culture "ngersaya" is one of the local cultural values in the District of Cirebon including Klangenan District as one of the districts residing in this district. "Ngersaya" is a local people's gratitude to anyone who has provided assistance or help to them. Their form of cooperative behavior towards aid providers, respecting and respecting aid providers and all those involved in providing assistance.
This value is very helpful for the smooth implementation of the Self-Helping Housing Stimulant Program. Conflicts triggered by protests or interruptions from beneficiaries are extremely rare. Beneficiaries are very cooperative and are patient in proposing, waiting for verified proposals, awaiting disbursements to the stage of implementation and completion of home improvements.

\subsection{Inter-organizational linkages and the effectiveness of implementation of self-helping housing stimulant program}

Klangenan District in 2017 earned the trust of the Ministry of Public Works and People's Housing to get a Self-Helping Housing Stimulant Charity. There are two villages that get this assistance is Jemaras Kidul and Jemaras Lor.

Table 1: Number of Beneficiaries of Self-Helping Housing Stimulant in Klangenan District, 2017

\begin{tabular}{|l|l|l|}
\hline Number & Name of Village & Unit of House \\
\hline 1 & Jemaras Kidul & 50 \\
\hline 2 & Jemaras Lor & 66 \\
\hline & Total Unit & 116 \\
\hline
\end{tabular}

Source: Government of West Java Province, 2017

Based on information from informants, all aid for 116 housing units in both villages can be completed until the end of 2017. This is a success for all parties involved. Although in the process there are still shortcomings such as coordination meetings that have not been intense. But overall it will all be completed by December 2017.

Parties involved in the Ministry of Public Works and Public Housing, Government of West Java Province, Cirebon Regency Government, Klangenan District Government, Jemaras Kidul Village Government, Jemaras Lor Village Government, Field Facilitator Team, Beneficiaries and Low Income Communities and village communities the whole realize the importance of cooperation and mutual understanding in implementing this program. This is evidenced by the success of all the teams involved in realizing the repair of 116 beneficiary houses in Klangenan District, Cirebon Regency.

\section{Conclusion}

Based on the results of research and discussion, it is concluded that inter-organizational linkages between the parties involved in the Self-Helping Housing Stimulant Program run quite harmoniously in a good cooperative relationship. Each step of the activity is done with coordination and mutual understanding between the parties.

Inter-organizational linkages are getting closer and warmer with the local culture of "ngersaya," which is the values shared by the people of Cirebon Regency in the form of a sense of pleasure and gratitude towards the aid providers embodied in cooperative behavior in the process of proposal, verification, disbursement and implementation of the program. All parties involved in this program can realize the implementation of the program marked by the completion of 116 home improvement in Jemaras Kidul Village and Jemaras Lor Village, Klangenan District, Cirebon Regency.

\section{References}

[1] Candradewini (2017), Kapasitas Inter-organizational Linkages Para Pemangku Kepentingan (Stakeholders) dalam Pengembangan Industri Kecil di Kota Sukabumi Jawa Barat, Adbispreneur Journal 2(2).

[2] Starling, Grover (2005), Managing Public Sector, 7th Edition Thompsons, Wadsworth United States.

[3] Lusthaus, Charles, et,.al, (2002), Organizational Assessment. A framework for improving performance, Ottawa: Inter-American 
Development Bank, Washington DC and International Development Research Centre.

[4] Wahab SA (2014), Analisis Kebijakan dan Formulasi ke Penyusunan, Model-Model Implementasi Kebijakan Publik, Jakarta: PT. Bumi Aksara.

[5] Agustino, Leo (2008), Dasar-Dasar Kebijakan Publik, Bandung: Alfabeta. 